\title{
The Effect of Different Induction Therapies on Graft Functions in Renal Transplantation \\ Gulay Yilmaz ${ }^{1}$, Can Sevinc ${ }^{2}$
}

1.Acibadem International Hospital, Department of Nephrology and Transplantation, Istanbul, Turkey, 2. Ataturk University Faculty of Medicine Department of Internal Medicine and Nephrology, Erzurum, Turkey

\begin{abstract}
Introduction: Rejection and delayed graft function (DGF) are frequent problems after renal transplant. The use of induction therapies increases graft survival and reduces acute rejection frequency. Here, we wanted to see one-year outcomes of patients who did not receive induction therapy and those who received basiliximab or anti-thymocyte globulin (rabbit) (rATG).

Patients and Methods: 741 renal transplant recipients were divided into 3 groups: 223 patients who received rATG, 213 who received basiliximab, and 305 patients who did not receive any induction therapy. Patients' demographic characteristics, ischemia times, creatinine levels, presence of DGF and acute rejection were studied.

Results: $35.6 \%(n=264)$ of the patients were female and $64.4 \%(n=477)$ were male; their ages were 4 to 72 years. During follow-up, 27 (3.6\%) patients had DGF and 152 (20.5\%) had acute rejection. There was no difference in DGF and rejection between the 3 groups.

Conclusion: Although there wasn't statistically difference in DGF, acute rejection, or 1- year creatinine levels between groups, the rATG group had higher hemodialysis rate, longer dialysis time, lower rate of preemptive transplantation, and lower mean age.
\end{abstract}

Keywords: Delayed graft function, Induction, Rejection, Renal transplantation

\section{INTRODUCTION}

Rejection and delayed graft function (DGF) are frequent problems after kidney transplantation ${ }^{(1)}$. However, treatment with induction agents, has increased graft survival and decreased the frequency of rejection ${ }^{(2)}$.

The T lymphocyte-suppressing agents; rATG and muromonab-CD3 have been used since 1980, followed by the introduction of basiliximab and daclizumab in the 90s. Studies on the impact of induction agents on rejection, DGF, and graft survival have yielded different results. Willoughby et al. compared 3 groups; one without induction therapy and those that received rATG or basiliximab, and they didn't find any difference between the groups in terms of acute rejection, graft and patient survival at posttransplant 6 months ${ }^{(3)}$. In their study conducted in 2015, Tanriover et al. compared similar groups and reported that the ATG group had less rejection, longer graft and patient survival ${ }^{(4)}$. Therefore, we also wanted to compare the 1-year outcomes of recipients who did not receive induction therapy and who received basiliximab or rATG therapy in terms of rejection and DGF.

\section{PATIENTS AND METHODS}

This retrospective chart review included 741 patients who underwent renal transplantation. The patients were divided into 3 groups:1- patients who received rATG induction,2- those who received basiliximab induction, and 3-those who did not receive induction therapy. The patients' demographic characteristics, panel reactive antibody (PRA) levels, posttransplant creatinine levels, DGF rates, and acute rejection attacks were compared in all groups. Relationships between human leukocyte antigen (HLA)-A mismatch (MM), HLA-BMM, HLADRMM, and total MM counts and DGF and acute rejection were evaluated.

\section{Ethical approval}

The study was approved by the Ethics Board of Acibadem University and an informed written consent was taken from each participant in the study.

\section{Statistical analysis \\ NCSS (Number Cruncher Statistical System) 2007 (Kaysville, Utah, USA) was used for statistical analysis. In addition to the descriptive statistical methods (mean, standard deviation, median, frequency, ratio, minimum, maximum), Student's t test was used for comparisons of 2 groups of normally distributed data and Mann-Whitney U test was used for comparisons of 2 groups of non-normally distributed data. In comparisons of 3 or more groups, one-way analysis of variance (ANOVA) was used for normally distributed data and Kruskal-Wallis test was used for non-normally distributed data. Friedman test was used in group evaluations of the follow-up data that did not show normal distribution and Wilcoxon signed ranks test were used for pairwise comparisons. Pearson chi-square test and Fisher's exact test were used to compare qualitative data. Statistical significance was accepted at $\mathrm{p}<0.05$.}




\section{RESULTS}

Descriptive characteristics of the patients are shown in table 1.

Table 1: Descriptive Characteristics

\begin{tabular}{|c|c|c|}
\hline Recipient age (years) & $\begin{array}{l}\text { Min-Max (Median) } \\
\text { Mean } \pm S D\end{array}$ & $\begin{array}{l}4-72(40) \\
38.83 \pm 14.27\end{array}$ \\
\hline Recipient gender, $n(\%)$ & Male & $477(64.4)$ \\
\hline & Female & $264(35.6)$ \\
\hline$\overline{\text { Donor age (years) }}$ & $\begin{array}{l}\text { Min-Max (Median) } \\
\text { Mean } \pm S D\end{array}$ & $\begin{array}{l}17-87(48) \\
47.62 \pm 13.27\end{array}$ \\
\hline Donor gender, $n(\%)$ & $\begin{array}{l}\text { Male } \\
\text { Female }\end{array}$ & $\begin{array}{l}302(40.8) \\
439(59.2)\end{array}$ \\
\hline Induction agent, $n(\%)$ & $\begin{array}{l}\text { ATG } \\
\text { Basiliximab } \\
\text { None } \\
\end{array}$ & $\begin{array}{l}223(30.1) \\
213(28.7) \\
305(41.2)\end{array}$ \\
\hline ATG total dose $(\mathrm{mg})(\mathrm{n}=223)$ & $\begin{array}{l}\text { Min-Max (Median) } \\
\text { Mean } \pm S D\end{array}$ & $\begin{array}{l}40-4500(750) \\
829.22 \pm 601.15\end{array}$ \\
\hline Cold ischemia time (min) & $\begin{array}{l}\text { Min-Max (Median) } \\
\text { Mean } \pm S D\end{array}$ & $\begin{array}{l}1.6-296(61) \\
74.23 \pm 42.91\end{array}$ \\
\hline Warm ischemia time (min) & $\begin{array}{l}\text { Min-Max (Median) } \\
\text { Mean } \pm S D\end{array}$ & $\begin{array}{l}10-900(72) \\
86.11 \pm 69.80\end{array}$ \\
\hline Dialysis type, $n(\%)$ & $\begin{array}{l}\text { Preemptive transplant } \\
\text { Hemodialysis } \\
\text { Peritoneal dialysis }\end{array}$ & $\begin{array}{l}72(9.7) \\
598(80.7) \\
71(9.6)\end{array}$ \\
\hline$\overline{\text { Dialysis time (months) }}$ & $\begin{array}{l}\text { Min-Max (Median) } \\
\text { Mean } \pm S D\end{array}$ & $\begin{array}{l}0-273(21) \\
37.46 \pm 42.82\end{array}$ \\
\hline$\overline{\text { DGF }, n(\%)}$ & $\begin{array}{l}\text { Yes } \\
\text { No }\end{array}$ & $\begin{array}{l}27(3.6) \\
714(96.4)\end{array}$ \\
\hline Acute rejection, $n(\%)$ & $\begin{array}{l}\text { Yes } \\
\text { No }\end{array}$ & $\begin{array}{l}589(79.5) \\
152(20.5)\end{array}$ \\
\hline
\end{tabular}

SD: Standard deviation, ATG: Anti-thymocyte globulin, DGF: Delayed graft function

Panel-reactive antibody (PRA) Class 1 and Class 2 rates were similar between the groups (Table 2).

Table 2: Panel-Reactive Antibody (PRA) Class 1 and Class 2 Evaluations by Groups

\begin{tabular}{|c|c|c|c|c|c|}
\hline & \multirow{3}{*}{\begin{tabular}{|c|}
$\begin{array}{c}\text { ATG } \\
(\mathrm{n}=349)\end{array}$ \\
$\mathrm{n}(\%)$ \\
\end{tabular}} & \multicolumn{2}{|l|}{ Groups } & \multirow{3}{*}{$p$} \\
\hline & & & $\begin{array}{c}\text { Basiliximab } \\
(\mathbf{n}=\mathbf{2 3 8})\end{array}$ & $\begin{array}{l}\text { No induction } \\
(n=368)\end{array}$ & \\
\hline & & & n $(\%)$ & n $(\%)$ & \\
\hline \multirow{2}{*}{ PRA Class 1} & Negative & $322(92.3)$ & $228(95.8)$ & $342(92.9)$ & \multirow[t]{2}{*}{0.214} \\
\hline & Positive & $27(7.7)$ & $10(4.2)$ & $26(7.1)$ & \\
\hline \multirow[t]{2}{*}{ PRA Class 2} & Negative & $330(94.6)$ & $229(96.2)$ & $351(95.4)$ & \multirow[t]{2}{*}{0.643} \\
\hline & Positive & $19(5.4)$ & $9(3.8)$ & $17(4.6)$ & \\
\hline
\end{tabular}

Mean creatinine levels in the whole group were $1.48 \pm 1.02$ at 1 week, $1.10 \pm 0.54$ at 3 months; and $1.20 \pm 0.47$ 1 year after transplant. There were no statistically significant relationships between cold or warm ischemia time and creatinine levels at any of the time points ( $p>0.05$ ).

Recipients who received ATG and basiliximab were significantly older than those who did not receive induction therapy. There was significant difference between the groups according to the type of dialysis applied. The frequency of preemptive transplantation was higher in basiliximab and no induction therapy groups compared to patients who received ATG. Hemodialysis was more frequent in ATG group than no induction therapy group, while peritoneal dialysis was more frequent in no induction therapy group compared to the ATG and basiliximab groups. Duration of dialysis was longer in recipients who received ATG than who received basiliximab or no induction therapy (Table 3). 
Table 3: Assessment of Descriptive Properties According to Induction Agent

\begin{tabular}{|c|c|c|c|c|c|}
\hline & \multicolumn{3}{|c|}{ Induction agent } & \multirow{2}{*}{$p$-value } \\
\hline & & $\overline{\text { ATG (n=223) }}$ & Basiliximab $(n=213)$ & None $(n=305)$ & \\
\hline \multirow{2}{*}{$\begin{array}{l}\begin{array}{l}\text { Recipient age } \\
\text { (years) }\end{array} \\
\end{array}$} & Min-Max (Median) & $5-71(45)$ & $\overline{~ 10-72(44)}$ & 4-67 (33) & \multirow[t]{2}{*}{$0.001 * *$} \\
\hline & $M e a n \pm S D$ & $42.79 \pm 13.45$ & $41.98 \pm 13.46$ & $33.74 \pm 13.87$ & \\
\hline \multirow{2}{*}{$\begin{array}{l}\text { Recipient gender; } \\
n(\%)\end{array}$} & Male & $152(68.2)$ & $135(63.4)$ & $190(62.3)$ & \multirow[t]{2}{*}{0.357} \\
\hline & Female & $71(31.8)$ & $78(36.6)$ & $115(37.7)$ & \\
\hline \multirow[t]{2}{*}{ Donor age (years) } & Min-Max (Median) & $17-76(47)$ & $19-84(48)$ & $18-87(49)$ & \multirow[t]{2}{*}{0.363} \\
\hline & $M e a n \pm S D$ & $47.39 \pm 12.05$ & $46.73 \pm 12.67$ & $48.42 \pm 14.47$ & \\
\hline \multirow{2}{*}{$\begin{array}{l}\text { Donor gender; } \\
n(\%)\end{array}$} & Male & $84(37.7)$ & $95(44.6)$ & $123(40.3)$ & \multirow[t]{2}{*}{0.332} \\
\hline & Female & $139(62.3)$ & $118(55.4)$ & $182(59.7)$ & \\
\hline \multirow{2}{*}{$\begin{array}{l}\text { Cold ischemia time } \\
(\mathrm{min})\end{array}$} & Min-Max (Median) & $1.6-288(62)$ & $17-296(62)$ & $5-240(58)$ & \multirow[t]{2}{*}{$0.004 * *$} \\
\hline & $M e a n \pm S D$ & $75.69 \pm 44.91$ & $84.03 \pm 52.83$ & $66.31 \pm 30.53$ & \\
\hline \multirow{2}{*}{$\begin{array}{l}\text { Warm ischemia } \\
\text { time (min) }\end{array}$} & Min-Max (Median) & $32-655(70)$ & $22-755(74)$ & $10-900(70)$ & \multirow[t]{2}{*}{$0.008 * *$} \\
\hline & Mean $\pm S D$ & $82.65 \pm 51.07$ & $91.44 \pm 67.78$ & $84.92 \pm 81.98$ & \\
\hline \multirow[t]{3}{*}{ Dialysis type, $n(\%)$} & $\begin{array}{l}\text { Preemptive } \\
\text { transplant }\end{array}$ & $10(4.5)$ & $25(11.7)$ & $37(12.1)$ & \multirow[t]{3}{*}{$0.001 * *$} \\
\hline & Hemodialysis & $197(88.3)$ & $174(81.7)$ & $227(74.4)$ & \\
\hline & Peritoneal dialysis & $16(7.2)$ & $14(6.6)$ & $41(13.4)$ & \\
\hline \multirow{2}{*}{$\begin{array}{l}\begin{array}{l}\text { Dialysis time } \\
\text { (months) }\end{array} \\
\end{array}$} & Min-Max (Median) & $0-273(32)$ & $0-261(18)$ & $0-220(16.5)$ & \multirow[t]{2}{*}{$0.002 * *$} \\
\hline & $M e a n \pm S D$ & $43.40 \pm 44.71$ & $35.07 \pm 42.60$ & $34.82 \pm 41.26$ & \\
\hline \multirow[t]{2}{*}{ DGF; $n(\%)$} & Yes & $13(5.8)$ & $7(3.3)$ & $7(2.3)$ & \multirow[t]{2}{*}{0.096} \\
\hline & No & $210(94.2)$ & $206(96.7)$ & $298(97.7)$ & \\
\hline \multirow{2}{*}{$\begin{array}{l}\text { Acute rejection, } n \\
(\%)\end{array}$} & Yes & $169(75.8)$ & $165(77.5)$ & $255(83.6)$ & \multirow[t]{2}{*}{0.061} \\
\hline & No & $54(24.2)$ & $48(22.5)$ & $50(16.4)$ & \\
\hline
\end{tabular}

SD: Standard deviation, ATG: Anti-thymocyte globulin, DGF: Delayed graft function, *: Significant difference,

HLA-AMM, HLA-BMM, HLA-DRMM, and total MM counts were higher in the ATG and basiliximab groups compared to the no induction therapy group (Table 4).

Table 4: Assessment of Human Leukocyte Antigen (HLA) Mismatch Counts and Creatinine Measurements According to Induction Agent

\section{Induction Agent}

\section{ATG (n=223) Basiliximab $(\mathbf{n}=213)$}

\begin{tabular}{|c|c|c|c|c|c|}
\hline \multirow[t]{2}{*}{ HLA-A MM } & $\begin{array}{l}\text { Min-Max } \\
\text { (Median) }\end{array}$ & $0-2(1)$ & $0-2(1)$ & $0-2(1)$ & $0.001 * *$ \\
\hline & $M e a n \pm S D$ & $1.35 \pm 0.63$ & $1.36 \pm 0.64$ & $0.85 \pm 0.55$ & \\
\hline \multirow[t]{2}{*}{ HLA-B MM } & $\begin{array}{l}\text { Min-Max } \\
\text { (Median) }\end{array}$ & $0-2(2)$ & $0-2(1)$ & $0-2(1)$ & $0.001 * *$ \\
\hline & $M e a n \pm S D$ & $1.44 \pm 0.64$ & $1.38 \pm 0.67$ & $0.88 \pm 0.52$ & \\
\hline \multirow[t]{2}{*}{ HLA-DR MM } & $\begin{array}{l}\text { Min-Max } \\
\text { (Median) }\end{array}$ & $0-2(1)$ & $0-2(1)$ & $0-3(1)$ & $0.001 * *$ \\
\hline & Mean $\pm S D$ & $1.38 \pm 0.60$ & $1.34 \pm 0.67$ & $0.85 \pm 0.53$ & \\
\hline \multirow[t]{2}{*}{ Total MM } & $\begin{array}{l}\text { Min-Max } \\
\text { (Median) }\end{array}$ & $0-6(4)$ & $0-6(5)$ & $0-6(3)$ & $0.001 * *$ \\
\hline & $M e a n \pm S D$ & $4.27 \pm 1.27$ & $4.22 \pm 1.49$ & $2.98 \pm 1.46$ & \\
\hline \multirow[t]{2}{*}{$\begin{array}{l}\text { 1-week Creatinine } \\
\text { (mg/dl) }\end{array}$} & $\begin{array}{l}\text { Min-Max } \\
\text { (Median) }\end{array}$ & $0-9.2(1.3)$ & $0.5-5.9(1.3)$ & $0.3-9.5(1.2)$ & $0.020 *$ \\
\hline & $M e a n \pm S D$ & $1.63 \pm 0.19$ & $1.44 \pm 0.39$ & $1.41 \pm 0.01$ & \\
\hline \multirow[t]{2}{*}{$\begin{array}{l}\text { 3-month Creatinine } \\
\text { (mg/dl) }\end{array}$} & $\begin{array}{l}\text { Min-Max } \\
\text { (Median) }\end{array}$ & $0-2.9(1.1)$ & $0-4.6(1.1)$ & $0-3.9(1.1)$ & $0.022 *$ \\
\hline & $M e a n \pm S D$ & $1.07 \pm 0.49$ & $1.19 \pm 0.31$ & $1.05 \pm 0.12$ & \\
\hline \multirow[t]{2}{*}{$\begin{array}{l}\text { 1-year Creatinine } \\
\text { (mg/dl) }\end{array}$} & $\begin{array}{l}\text { Min-Max } \\
\text { (Median) }\end{array}$ & $0-3(1.2)$ & $0.1-5.4(1.1)$ & $0-3.3(1.1)$ & 0.885 \\
\hline & $M e a n \pm S D$ & $1.19 \pm 0.39$ & $1.22 \pm 0.13$ & $1.20 \pm 0.19$ & \\
\hline
\end{tabular}

MM: Mismatch 


\section{DISCUSSION}

New drugs developed for induction and maintenance therapy have significantly reduced the frequency of rejection in patients with kidney transplantation. By using ATG, which is a polyclonal antilymphocyte antibody prevention and treatment of rejections became easier. ATG is associated with serious adverse effects such as neutropenia, thrombocytopenia and allergic reactions. Therefore, in 1986 OKT3 was developed as an alternative to ATG. This was followed by another monoclonal antibody, alemtuzumab, which is an Ig2b antibody against CD52 antigen. Rituximab is also an anti-CD20 antibody used for desensitization and humoral rejection therapy. In 1998, basiliximab and daclizumab were introduced. The target of these two agents is the IL-2 receptor. Both agents are used in induction therapy ${ }^{(5)}$.

Induction therapy is used to prevent acute rejection. Agents commonly used for this purpose are ATG or IL-2 receptor antibody (IL2RAB). ATG, which reduces lymphocyte count and is also used in the acute rejection treatment, is more potent than IL2RAB ${ }^{(6)}$. rATG binds $\mathrm{T}$ lymphocytes and bounded $\mathrm{T}$ lymphocytes are removed by the reticuloendothelial system. Basiliximab inhibits the activation of $\mathrm{T}$ lymphocytes without decreasing their count ${ }^{(7)}$. Many studies about induction therapy agents have yielded contradictory results. The question is whether all patients should receive induction therapy and which agents should be preferred. Brennan et al. made a study to compare rATG and basiliximab. Acute rejection occurred in $15.6 \%$ of patients receiving rATG and $25.5 \%$ of patients receiving basiliximab within the first year. However, no difference was found between the groups in terms of either patient survival or graft survival at the first year after transplantation. In addition, DGF rates between the two groups were similar ${ }^{(8)}$.

In another study comparing rATG and basiliximab, no difference was found in terms of acute rejection, graft survival, or patient survival in the first year ${ }^{(9)}$. Hanaway et al. classified patients as high-risk and low-risk. They compared alemtuzumab, basiliximab and rATG in both groups. They found less rejection compared to basiliximab in low-risk patients who were treated with alemtuzumab. They also observed that there was no difference in rejection in the first 3 years between high-risk patients treated with alemtuzumab and patients treated with rATG. They obtained similar results in both graft survival and patient survival in both risk groups ${ }^{(10)}$. We found no difference between the 3 groups in terms of neither acute rejection nor DGF.

It is known that graft survival is much better in preventive transplants and in patients receiving dialysis treatment for a shorter period of time. Jay $\boldsymbol{e t}$ al. grouped patients as those who had preemptive transplantation, those who had dialysis less than 1 year, and those who had dialysis for more than 1 year, and reported that the 5-year graft survival was better in the preemptive group ${ }^{(11)}$. The association between donor and recipient ages and graft/patient survival has been evaluated in many studies. Moghani-Lankarani et al. compared 6-month, 1-year, and 5-year graft survival in renal transplant patients over 60 years old patients and under 60 years old patients. They saw that there was no difference between the groups at 6 months or 1 year, but they also saw that graft survival at 5 years was better in transplant patients under 60 years old ${ }^{(12)}$. In another study, they evaluated the relationship between recipient and donor ages and graft survival and determined that older recipients and donors over 60 years of age were associated with poorer survival ${ }^{(13)}$. Our findings are consistent with the literature.

In this study, there was no difference between the groups in terms of 1-year creatinine levels. However, patients who had induction therapy may be higher risk patients and this may affect the outcome. A study which compared immunological factors and renal graft function at the end of 1 year, it was found that HLA-MM count was the determinant of graft survival ${ }^{(14)}$. Immune risk may be the most important factor besides the various factors affecting graft survival such as recipient and donor age, ischemia time, primary renal disease and immunosuppressive therapy.

Although immune risk is a determinant, it is essential when planning induction therapy to consider other risk factors and adverse effect profiles that determine choice of treatment. Serious adverse effects such as bone marrow suppression, infections, posttransplant lymphoproliferative disease, and malignancy may be associated with immunosuppressive therapy. Although the results of the studies are contradictory in terms of graft survival and acute rejection, ILRAB appears to be safer in terms of side effect profile. ${ }^{(15)}$.

\section{CONCLUSION}

Although immunologic risk is the most important parameter determining graft survival and acute rejection in renal transplantation, selection of induction agent and immunosuppressive therapy should be patient-specific considering other risk factors and adverse effects.

\section{REFERENCES}

1. Wu et alK, Famure O, Li Y et al. (2015): Delayed graft function and the risk of acute rejection in the modern 
era of kidney transplantation. Kidney international, 88(4), 851-858.

2.Tian H, Wang X, Yang $H$ et al. (2009): Induction with and without antithymocyte globulin combined with cyclosporine/tacrolimus-based immunosuppression in renal transplantation: A meta-analysis of randomized controlled trials. Transplant Proc.,41: 3671-3676.

3. Willoughby M, Schnitzler A, Brennan C et al. (2009): Early outcomes of thymoglobulin and basiliximab induction in kidney transplantation: Application of statistical approaches to reduce bias in observational comparisons. Transplantation ,87(10):1520-1529.

4. Tanriover B, Zhang S, Mac Conmara M et al. (2015): Induction therapies in live donor kidney transplantation on tacrolimus and mycophenolate with or without steroid maintenance. Clinical Journal of the American Society of Nephrology CJASN., 10(6):1041-1049.

5. Gabardi S, Martin T, Roberts L et al. (2011): Induction immunosuppressive therapies in renal transplantation. Am J Health Syst Pharm., 68:211-218.

6. Webster A, Pankhurst T, Rinaldi F et al. (2006): Polyclonal and monoclonal antibodies for treating acute rejection episodes in kidney transplant recipients. DOI: $10.1002 / 14651858$.

7.Hardinger L, Brennan C, Klein L (2013): Selection of induction therapy in kidney transplantation. Transpl Int., 26: 662-672.

8. Brennan C, Daller A, Lake D et al. (2006): Rabbit antithymocyte globulin versus basiliximab in renal transplantation. N Eng J Med., 355: 1967-1977.
9. Lebranchu Y, Bridoux F, Buchler M et al. (2002): Immunoprophylaxis with basiliximab compared with antithymocyte globulin in renal transplant patients receiving MMF-containing triple therapy. Am J Transplant .,2: 48-56.

10. Hanaway J, Woodle S, Mulgaonkar S et al. (2011): Alemtuzumab induction in renal transplantation. N Engl J Med .,364: 1909-19.

11. Jay L, Dean G, Helmick RA, Stegall D (2016): Reassessing preemptive kidney transplantation in the United States: Are we making progress? Transplantation, 100(5):1120-1127.

12.Moghani-Lankarani M, Assari S, Sharifi-Bonab M et al. (2010): Does age of recipient affect outcome of renal transplantation? Ann Transplant., 15(2): 21-26.

13.Pahwa M, Chawla A, Dar I et al. (2014): Live donor kidney transplantation in India: effects of donor and recipient age on graft survival. Ren Fail, 36(2): 222224.

14. Coupel S, Giral-Classe M, Karam G et al. (2003): Ten-year survival of second kidney transplants: Impact of immunologic factors and renal function at 12 months. Kidney Int .,64:674-680.

15.Pascual J, Marcén R, Ortuño J (2001): Antiinterleukin-

2 receptor antibodies: basiliximab and daclizumab. Nephrol Dial Transplant., 16(9):1756-60. 